\title{
Heavy Metal Adsorption to a Chelating Resin in a Binary Solid Fluidized Bed
}

\author{
By Jianzhong Yang and Albert Renken*
}

The addition of inert particles of lighter density and smaller diameter increases considerably the mass transfer coefficient in comparison to that of mono-component active particles at the same liquid velocity. This effect was applied to elimination of copper ions by adsorption on a chelating resin. An intensification of the film mass transfer coefficient in binary system leads to a $15 \%$ increase of the usable adsorbent efficiency.

\section{Introduction}

Wastewater generated by electroplating contains a substantial amount of metal ions and the recovery of these metal ions is becoming of increasing importance for the protection of the environment. The development of efficient separation processes is leading to an increased interest in the engineering aspects. Many techniques can be used for pre-concentration of trace amounts of metal ions, and among these, adsorption of metal ions with chelating resins is an effective and powerful separation technology. Adsorption processes are traditionally carried out in fixed beds [1-5] due to the high concentration of solids and the obtainable uniform residence time. However since the wastewater to be treated often contains solid impurities leading to a plugging of the fixed bed, the liquid must be clear to avoid column blocking.

Another problem concerns shrinking and swelling of the resin during the adsorption/desorption processes resulting in poor liquid distribution caused by channeling and formation of dead zones [6-7]. Therefore many experimental studies have been conducted in fluidized beds, which allow treatment of turbid liquids while avoiding the channeling problems [8-14].

For a proper design of the fluidized bed adsorber, an adequate mathematical model is required which takes into account the hydrodynamics and adsorption kinetics. Menoud et al [15] studied the adsorption kinetics of a chelating resin (Chelamine JPS-Chimie, Neuchâtel, Switzerland [16]) and found that the overall adsorption rate is limited by external mass transfer. Therefore intensification of the mass transfer should increase the performance of the fluidized bed adsorber for such an adsorption system.

According to our previous work [17], the addition of inert particles of heavier density and smaller diameter could be used to increase the film mass transfer coefficient. In this work, this technique is applied to the aforementioned system. A comparison is made of copper ion removal in monocomponent and binary solid systems, thereby providing the information to understand the changing tendency of adsorption process at different mass transfer coefficients and to evaluate the influence extent of small/heavier inert particles on adsorption performance.

[*] Dr. J. Yang, Prof. Dr. A. Renken, Laboratory of Chemical Reaction Engineering, Swiss Federal Institute of Technology, CH-1015 Lausanne, Switzerland.

\section{Adsorption Model in a Fluidized Bed}

The governing equations for the adsorption of copper ion in a fluidized bed can be derived on the base of the research results of the equilibrium isotherm and hydrodynamics of liquid and solid particles [15]. In the development of the mathematical model, several simplifying assumptions are made as follows :

- Adsorption rate is limited by a liquid film resistance and surface reaction.

- Surface reaction between adsorbate and adsorption site is described by a reversible second order reaction. Adsorption equilibrium behavior is represented by the Langmuir isotherm.

- Adsorbent particles are spherical with a mean diameter $d_{p}$. These particles are relatively immobile and distributed uniformly in the column.

- Axial dispersion of liquid is negligible.

A material balance of the cation in the mobile phase for such a system gives rise to ${ }^{1)}$

$\varepsilon_{r} \frac{\partial c}{\partial t}=-u \frac{\partial c}{\partial z}-R_{i}$

The adsorption rate from the bulk solution to the surface of particles is :

$R_{i}=k_{L} a\left(c-c_{i}\right)$

Where $a$ is the surface area of the particles per reactor unit volume; $c$ is the bulk concentration; $k_{L}$, the film mass transfer coefficient; the temporal point concentration of solute $c_{i}$ can be calculated by a mass balance at the liquid-solid interface:

$\varepsilon_{r} \frac{\partial c_{i}}{\partial t}=k_{L} a\left(c-c_{i}\right)-\left(1-\varepsilon_{r}\right) \rho_{p} \frac{\partial q}{\partial t}$

The reaction rate in the solid phase is related to the interface concentration $c_{i}$ and described by the Langmuir isotherm:

$\frac{\partial q}{\partial t}=k_{f}\left(c_{i}\left(q_{m}-q\right)-K_{d} q\right)$

$K_{d}=\frac{k_{r}}{k_{f}}$

1) List of symbols at the end of the paper. 
Where the parameters $k_{f}$ and $k_{r}$ are the rate constants of forward and reverse reaction, respectively; $K_{d}$, the dissociation constant; $q_{m}$, maximum capacity of resin.

The initial and boundary conditions would be

$$
\begin{aligned}
& c=0 \quad q=0 \text { at } t=0 \\
& c=c_{0} \text { at } z=0, t>0 \\
& \frac{\partial c}{\partial z}=0 \text { at } z=h, t>0
\end{aligned}
$$

The mass balance for the adsorbate is a partial differential equation. This equation can be reduced to an ordinary differential equation using the finite difference method. It is assumed that a fluidized bed of total volume $V$ can be divided into $N$ equal size cells in series and that the liquid flowing upwards passes through the bed. Furthermore, in order to compare the model with different experimental results, it is convenient to use the following dimensionless variables:

$$
\begin{aligned}
f & =\frac{c}{c_{0}} \\
\xi & =\frac{q}{q_{0}} \\
\theta & =\frac{t}{\tau_{m}}=\frac{Q c_{0} t}{m q_{0}} \\
\tau_{m} & =\frac{m q_{0}}{Q c_{0}}
\end{aligned}
$$

The variables $f$ and $\xi$ are dimensionless concentrations in liquid and solid phases respectively; $\theta$, the dimensionless time; $\tau_{m}$, the time required for saturating all the resin in the reactor; $c_{0}$, the concentration of cation at the inlet of the column; $q_{0}$, the dynamic capacity of the resin which is in equilibrium with $c_{0} ; m$, the mass of dry resin; $Q$, the flow rate of liquid.

After transformation with these dimensionless variables, the mass balance for the $j^{\text {th }}$ cell becomes:

$$
\begin{aligned}
& \frac{d f_{j}}{d \theta}=N \cdot \psi \cdot\left(f_{j-1}-f_{j}\right)-D a I_{k L} \cdot \psi \cdot\left(f_{j}-f_{i, j}\right) \\
& \frac{d f_{i, j}}{d \theta}=D a I_{k L} \cdot \psi\left(f_{j}-f_{i, j}\right)-\psi \frac{d \xi_{j}}{d \theta} \\
& \frac{d \xi_{j}}{d \theta}=\frac{D a I_{k f}}{\xi_{m}}\left(f_{i, j}\left(\xi_{m}-\xi_{j}\right)-\left(\xi_{m}-1\right) \xi_{j}\right)
\end{aligned}
$$

While developing the differential equations, several dimensionless groups are introduced. Some explications for these parameters are given as follows:

- $D a I_{k L}$ is a Damköhler number, which is defined by:

$$
D a I_{k L}=\frac{k_{L} a \tau}{\varepsilon_{r}}
$$

$D a I_{k L}$ represents the number of film mass transfer units which is the ratio between the hydraulic residence time and a characteristic time of adsorption [18]. For a fixed residence time, if the value $\mathrm{DaI}_{\mathrm{kL}}$ is larger, the adsorption will be carried out at a higher rate and the concentration of solute at the exit of the column is lower.

- $D a I_{k f}$ is another Damköhler I number, which is given by :

$$
D a I_{k f}=\frac{k_{f} q_{m} m}{Q}
$$

This is an expression for the number of transfer units due to the intrinsic adsorption kinetics.

Two transfer units $D a I_{k L}$ and $D a I_{k f}$ can be combined as the resistances in series to yield the overall number of transfer units [19]:

$$
\frac{1}{D a I} \approx \frac{1}{D a I_{k L}}+\frac{1}{D a I_{k f}}
$$

- $\psi$ is a residence time number required to saturate all the resin in the reactor:

$$
\psi=\frac{\tau_{m}}{\tau}=\frac{m q_{0}}{\varepsilon_{r} c_{0} V}
$$

- $\xi_{m}$ is an equilibrium factor which is defined by:

$$
\xi_{m}=\frac{q_{m}}{q_{0}}=\frac{K_{d}}{c_{0}}+1
$$

The equilibrium factor depends on the concentration of solution $\mathrm{c}_{0}$ at the inlet of the column for a continuous adsorption process. If $\xi_{m} \rightarrow \infty$, the concentration of solution $c_{0}$ is in the linear region of the Langmuir isotherm curve; if $\xi_{m} \rightarrow 1$ the dynamic capacity $q_{0}$ approximates to the maximum capacity of the resin, the $c_{0}$ and $q_{0}$ are in the plateau region of the Langmuir isotherm curve.

The response at the exit of the column is given by the concentration $f_{N}$ and Eqs. (13), (14) and (15) must be solved simultaneously subject to the boundary conditions $\left(f_{j-1}=1\right.$ when $j=1$ and $\theta>0)$ and the initial conditions $\left(f_{j}, f_{i, j}\right.$, and $q_{j}$ are zero when $\theta=0(1 \leq \mathrm{j} \leq \mathrm{N}))$.

This two-resistance model can be used as a sole resistancelimiting model by giving a high value for another resistance coefficient. When the reaction rate is instantaneous, only the film mass transfer resistance controls the adsorption rate, the temporal point concentration $c_{i}$ in Eq. (2) can be directly calculated with the Langmuir equilibrium:

$c_{i}=\frac{q K_{d}}{q_{m}+q}$

Using this theoretical framework and a SimuSolv program (Dow Chemical Company) [20], the contributions of mass transfer processes and kinetics may be estimated and compared with the experimental results.

\section{Experimental}

\subsection{Materials}

The adsorbent used in this study is a resin, Chelamine Standard ${ }^{\circledR}$ (JPS-Chimie, Neuchâtel, Switzerland) [16]. The 
adsorbate is a copper ion solution prepared with pentahydrate cupric sulfate (Fluka-AG, Buchs, Switzerland). The inert particles are glass beads (Microbeads, Brugg, Switzerland). The mean particle sizes and other properties for glass beads and resins are summarized in Tab. 1.

\subsection{Experimental Protocol and Methods}

The fluidized bed reactor previously used [15] is modified and used for monitoring the effect of inert particles on the adsorption process. A column is comprised of five Plexiglas elements (52 mm inner diameter and $102 \mathrm{~mm}$ height) which are designed with a thermostatic double jacket. During the adsorption experiment, the copper ion solution $(\sim 30 \mathrm{ppm})$ in the tank is circulated through a heat exchanger using a peristaltic pump, then fed into the column. The flow rate is measured with a calibrated rotameter. The $p H$ is measured with an on-line $p H$ meter and the temperature is measured with a thermocouple, the results are recorded automatically with a data acquisition system (LabVIEW for windows, version 3.0, National Instruments Corporation).

To determinate the concentration of the copper ion, the effluent at the outlet of the column is continuously withdrawn by a peristaltic pump. In parallel, an EDTA solution $(0.1 \mathrm{M})$ is supplied at the same flow rate, thus complex solution of copper ion-EDTA produces a measurable color. The optical density of the complex solution of copper ion-EDTA is measured with an on-line UV/VIS spectrophotometer (Diode array spectrophotometer $8452 \mathrm{~A}$, Hewlett Packard) at $732 \mathrm{~nm}$ [20]. The results are recorded by a computer and converted to concentration according to the Lambert-Beer law [21].

The color of the resin changes from yellow to green and then becomes dark blue during the adsorption process. The resin at the bottom of the column is loaded initially and this can be observed clearly from the color change. The resin particles shrink due to the loading of copper ion, therefore the height of the suspension layer decreases during the adsorption process. The mean height is taken into account for calculating the reactor volume. The diameter of loaded resin $(340 \mu \mathrm{m})$ is used to determinate the mass transfer surface area.

For comparison, the operating conditions are kept identical for the two kinds of experiments. The only difference is that the glass beads $(30 \mathrm{ml})$ are added to the column for the experiments with the binary system. The detailed operating conditions for experiments MIX3 and NOR5 are given in Tab. 2.

Table 2. Operation conditions
Table1. Properties of solid particles in binary system.

\begin{tabular}{|l|c|c|c|}
\hline Parameter & Symbol & Value & Units \\
\hline Resin (Chelamine) & & & \\
\hline Mean volumetric diameter & $d_{p}$ & 414 & $\mu \mathrm{m}$ \\
\hline Particle porosity & $\varepsilon_{p}$ & 0.81 & - \\
\hline $\begin{array}{l}\text { Mass of dry resin per unit } \\
\text { volume of swollen resin }\end{array}$ & $\rho_{p s}$ & 158.4 & $\mathrm{~kg} \cdot \mathrm{m}^{-3}$ \\
\hline Apparent density & $\rho_{a p}$ & 1064 & $\mathrm{~kg} \cdot \mathrm{m}^{-3}$ \\
\hline Archimedes number & $A r$ & 46 & - \\
\hline Inert particles (glass beads) & & & \\
\hline Mean volumetric diameter & $d_{p}$ & 103 & $\mu \mathrm{m}$ \\
\hline Apparent density & $\rho_{p}$ & 2450 & $\mathrm{~kg} \cdot \mathrm{m}^{-3}$ \\
\hline Archimedes number & $A r$ & 15 & - \\
\hline
\end{tabular}

\section{Results and Discussion}

Typical adsorption experimental results (points) are shown as a function of dimensionless time $\theta$ in Fig.1 and Fig.2. The $p H$ profiles (dotted curves) are also given in the same figures.

A comparison is made firstly between the film mass transfer and intrinsic adsorption kinetics with the two-resistance model. By using the film mass transfer coefficient and the intrinsic forward rate constant which are obtained with simulation, the number of transfer units for film mass transfer $D a I_{k L}$ and the number of transfer units for the intrinsic adsorption kinetics $D a I_{k f}$ are calculated by Eq. (16) and Eq.

\begin{tabular}{|l|c|c|c|c|}
\hline Operating parameters & Symbol & MIX3 & NOR5 & Units \\
\hline Operation temperature & $T$ & 20.0 & 20.0 & ${ }^{\circ} \mathrm{C}$ \\
\hline pH for preconditioning of resin & $p H_{0}$ & 13 & 13 & - \\
\hline Height of free settled bed & $h_{0}$ & 0.118 & 0.108 & $\mathrm{~m}$ \\
\hline Height of resin in fluidized bed & $h$ & 0.20 & 0.20 & $\mathrm{~m}$ \\
\hline Voidage of reactor & $\varepsilon_{r}$ & 0.662 & 0.662 & - \\
\hline Liquid flow rate & $Q$ & $3.963 \cdot 10^{-6}$ & $3.900 \cdot 10^{-6}$ & $\mathrm{~m}^{3} \cdot \mathrm{s}^{-1}$ \\
\hline Volume of reactor & $V$ & $4.248 \cdot 10^{-4}$ & $4.248 \cdot 10^{-4}$ & $\mathrm{~m}^{3}$ \\
\hline Residence time & $\tau$ & 71 & 72 & $\mathrm{~s}$ \\
\hline Feed concentration of $C u^{2+}$ & $c_{0}$ & 0.4637 & 0.4809 & $\mathrm{~mol}^{-3} \mathrm{~m}^{-3}$ \\
\hline Mass of dry resin & $m$ & 0.0227 & 0.0227 & $\mathrm{~kg}$ \\
\hline Volume of free settled resin & $V_{0}$ & $2.0 \cdot 10^{-4}$ & $2.0 \cdot 10^{-4}$ & $\mathrm{~m}{ }^{3}$ \\
\hline Voidage of free settled resin & $\varepsilon$ & 0.334 & 0.334 & - \\
\hline Volume of free settled glass beads & $V_{0 g}$ & $3.0 \cdot 10^{-5}$ & - & $\mathrm{m}^{3}$ \\
\hline Surface area per unit volume & $a$ & 3303 & 3303 & $\mathrm{~m}^{2} \cdot \mathrm{m}^{-3}$ \\
\hline
\end{tabular}




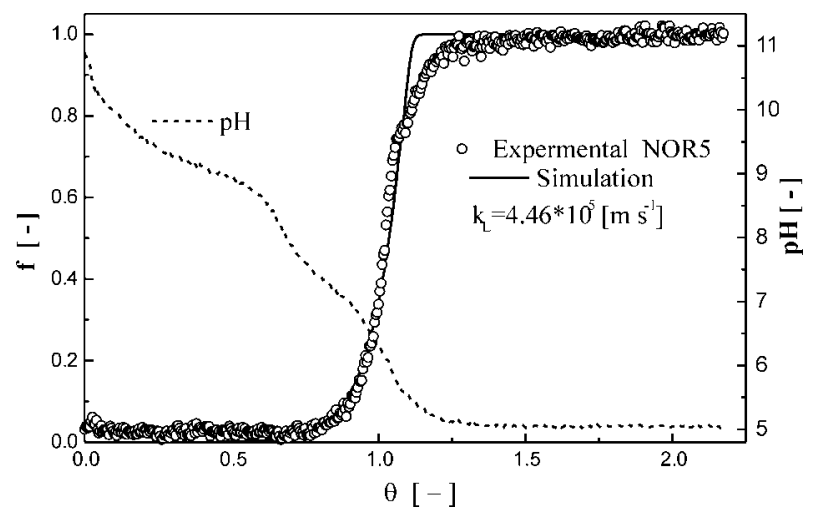

Figure 1. Experimental data and modeling of normal adsorption of copper ion onto Chelamine resin.

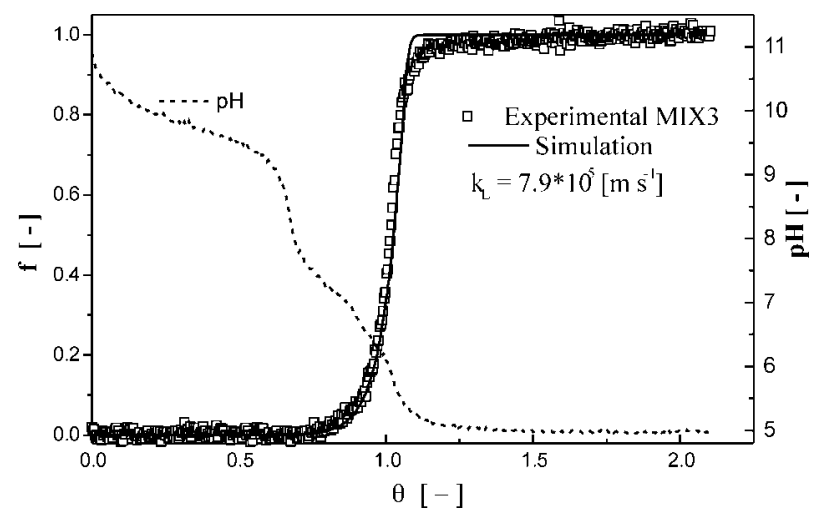

Figure 2. Experimental and modeling results on the adsorption of $\mathrm{Cu}^{2+}$ onto Chelamine resin in the suspension of glass beads.

(17), respectively. The number of transfer units for the adsorption of copper ion on chelating resin (experiment NOR5) is found to be respectively 145 for $D a I_{k f}$, and 16 for $D a I_{k L}$. The overall number of transfer units $D a I$ is calculated by Eq. (18), and has a value of 14 . The number of transfer units for the intrinsic adsorption kinetics is about 9 fold higher than that for the film mass transfer. This indicates that the surface interaction is much faster than the film mass transfer and the overall adsorption rate is limited mainly by the film mass transfer for this system.

Since the film mass transfer resistance appears to be the controlling step for the overall adsorption rate, a one parameter model, in which only the film mass transfer is considered, is sufficient. The simulated curve describes the experimental data reasonably well, however, at the second breakthrough point, the two-resistance model fits better than the one resistance model (results not shown here) [20]. This suggests that the surface reaction becomes more important when the resin approaches saturation. In other words, there is a lateral interaction between adsorbed molecules, the assumption in the Langmuir model does not held true for this case. Since the volume of resin particles decreases with loading of copper ion, the adsorbed cations exert an effect on the interaction between new solute and active sites. A decrease of $k_{f}$ is possibly due to steric change of the resin or pore blockage by adsorbed cations. Koloini and Zumer [22] thought that after approximately $80 \%$ of the resin capacity is exhausted the internal resistance to the adsorption process becomes important and the overall rate of the ion exchange decreases continuously. This behavior has been observed by other authors [18, 23] for protein adsorption in fixed beds. Therefore the two-resistance model is recommended for the following process simulation.

For the sake of comparison of the influence of inert particles on the film mass transfer coefficient, the forward rate constant and isotherm equilibrium constant are assumed to be fixed $\left(k_{f}\right.$ $\left.=2 \cdot 0^{-2} \mathrm{~m}^{3} \cdot \mathrm{mol}^{-1} \cdot \mathrm{s}^{-1}, K_{d}=0.0067 \mathrm{~mol} \mathrm{~m}{ }^{-3}\right)$ [14]. The liquid film mass transfer coefficient is a free parameter, with a value determined by fitting the experimental data. As typical examples simulation results for a mono-component (NOR5) and a binary-mixture systems (MIX3) are shown in Fig.1 and Fig.2 respectively. The prediction of the model (curve) for fluidized bed performance results in a good agreement. The values for the mass transfer coefficient obtained with the simulations are $4.4 \cdot 10^{-5}\left(\mathrm{~m} \cdot \mathrm{s}^{-1}\right)$ for the mono-component system and $7.9 \cdot 10^{-5}\left(\mathrm{~m} \cdot \mathrm{s}^{-1}\right)$ for the binary mixture system. The film mass transfer coefficient is substantially higher in the binary-mixture system and this confirmed once again that the small/heavier inert particles can be applied to intensify the external mass transfer.

From the engineering point of view, the main requirement for rational design is an estimate of the dynamic capacity of the fluidized bed. Assuming that the adsorption column is used to remove a trace impurity from a stream, a maximum permissible concentration at the outlet of the column is required, due to the legislation for the provision of water contamination. For example, the permissible concentration of $\mathrm{Cu}^{2+}$ in the effluent water should be less than $0.5 \mathrm{ppm}$ in Switzerland and Germany [24-25]. During the adsorption process, the effluent concentration at the outlet of the column increases gradually. The operation should be stopped when the effluent concentration reaches the maximum permissible concentration. The corresponding time may be called break time $\theta_{b}$. The dynamic capacity of the bed depends on the break time and can be calculated from the following mass balance:

$q=q_{0} \int_{0}^{\theta_{b}}(1-f) d \theta-\frac{\varepsilon_{r} c_{0}}{m} \int_{0}^{f} V d f$

Assuming that the quantity of metal ions in the liquid phase of the reactor is negligible compared to the adsorbed one, the usable fraction of the total capacity of adsorbents may be expressed using the following approximate relationship:

$\eta=\frac{q}{q_{0}} \approx \int_{0}^{\theta_{b}}(1-f) d \theta$

Defined in this way, the usable fraction of the total capacity of adsorbents in the column can be represented by the shaded area in Fig 3. 


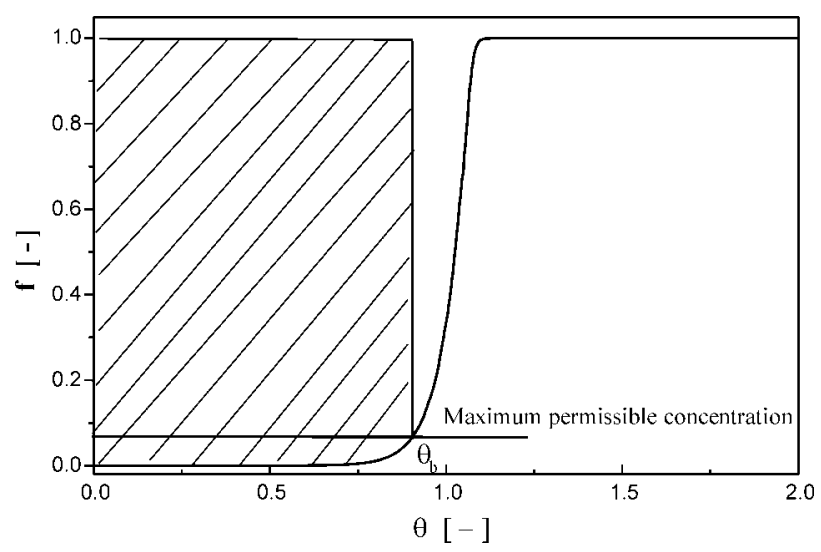

Figure 3. Usable efficiency of total capacity of adsorbents in the column.

For given operating conditions, the effluent concentration at the outlet of column changes during the adsorption process and forms an asymptotic breakthrough. The shape of the breakthrough curve is depending on the mass transfer rate as shown in Fig. 4. With increasing mass transfer coefficient, the effluent concentration at the outlet of the column decreases and the break time $\theta_{b}$ is postponed. Therefore the usable fraction of absorbents increases with increasing the mass transfer coefficient. Due to the higher mass transfer rate in a binary fluidized system, the break time increases from $\theta_{\mathrm{b} 1}$ to $\theta_{\mathrm{b} 2}$, resulting in a $15 \%$ higher usable fraction of the adsorbent.



Figure 4. Influence of mass transfer coefficient on break time.

The influence of the mass transfer coefficient on the break time and therefore the usable fraction of the adsorbent is summarized in Fig. 5, where the relationship between the usable fraction $\eta$ is plotted as function of the mass transfer coefficient $\mathrm{k}_{\mathrm{L}}$ in the fluidized bed adsorber. As shown in Fig. 5 for the given operating conditions of experiment Mix3, the usable fraction is nearly zero, if the mass transfer coefficient is less then $1.3 * 10^{-5}(\mathrm{~m} / \mathrm{s})$. That means that the concentration at the outlet of the column is higher than the permissible concentration at the beginning of the operation process. With increasing mass transfer coefficient, the usable fraction $\eta$ increases sharply in the range of $\mathrm{k}_{\mathrm{L}}=1.3 \sim 3 * 10^{-5}(\mathrm{~m} / \mathrm{s})$, and is then followed by a gradual increase at higher values.

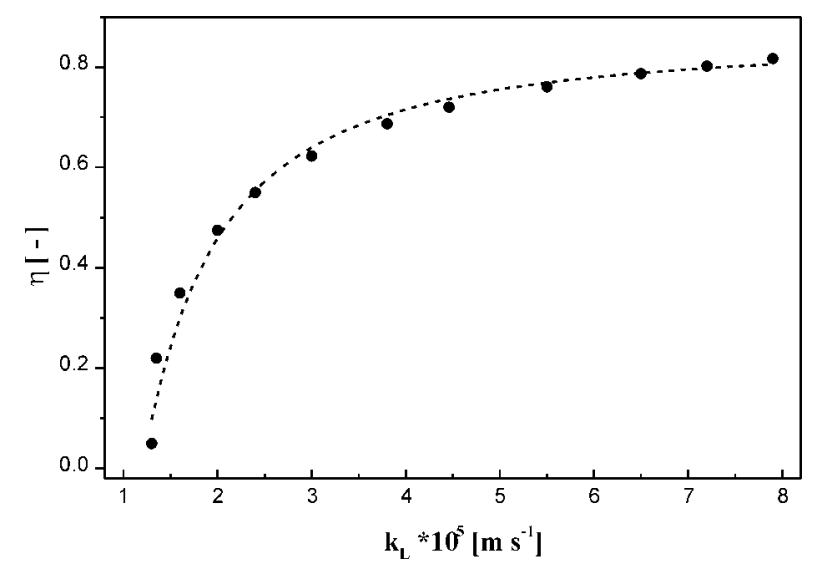

Figure 5. Influence of mass transfer coefficient on usable efficiency of adsorbents in the column.

\section{Conclusions}

Adsorption processes of copper ions onto a chelating resin in fluidized beds are studied experimentally and simulated with theoretical models. Comparison of the number of transfer units for film mass transfer and the number of transfer units for intrinsic adsorption kinetics indicate that the overall adsorption rate is limited mainly by the film mass transfer resistance for this system.

Small/heavier inert particles (glass beads) are used to mix with the resin particles during the adsorption of metal ion in the liquid fluidized bed. The experimental and theoretical results prove that the addition of inert glass beads exerts a significant positive effect on the film mass transfer coefficient.

For an adsorption process in which surface film resistance is the limiting step, an increase of the film mass transfer coefficient will result in a decrease of the effluent concentration at the outlet of the reactor and a postponement of the break time $\theta_{b}$ or prolongation of the operating time resulting in a significant increase of the usable fraction of adsorbent $\eta$ as defined in Eq.(23).

\section{Acknowledgement}

Financial support by the Commission for Technology and Innovation, Switzerland is gratefully acknowledged.

Received: January 10, 2000 [CET 1189]

\section{Symbols used}

$\begin{array}{ll}a & {\left[\mathrm{~m}^{2} \mathrm{~m}^{-3}\right]} \\ \text { Ar } & {[-]} \\ & \\ \mathrm{c} & {\left[\mathrm{mol} \mathrm{m}^{-3}\right]} \\ c_{i} & {\left[\mathrm{~mol} \mathrm{~m}^{-3}\right]}\end{array}$

surface area per unit volume of reactor Archimedes number, $=d_{p}^{3}\left(\rho_{a p}-\rho\right) \rho g / \mu^{2}$

bulk concentration of liquid in reactor cation concentration at the liquid-solid interface 


\begin{tabular}{|c|c|c|}
\hline$c_{0}$ & {$\left[\mathrm{~mol} \mathrm{~m}^{-3}\right]$} & $\begin{array}{l}\text { cation concentration at inlet of the } \\
\text { reactor }\end{array}$ \\
\hline$d_{p}$ & {$[\mathrm{~m}]$} & mean particle diameter \\
\hline$D a I_{k f}$ & {$[-]$} & Damköhler I number $=\frac{k_{f} \cdot q_{m} \cdot m}{Q}$ \\
\hline$D a I_{k L}$ & {$[-]$} & Damköhler I number $=\frac{k_{L} \cdot a^{*} \cdot \tau}{\varepsilon_{r}}$ \\
\hline$f$ & {$[-]$} & $\begin{array}{l}\text { dimensionless liquid phase } \\
\text { concentration }\end{array}$ \\
\hline$h$ & {$[\mathrm{~m}]$} & height of particle layer in fluidized bed \\
\hline$h_{0}$ & {$[\mathrm{~m}]$} & $\begin{array}{l}\text { height of particle layer in free settled } \\
\text { bed }\end{array}$ \\
\hline$K_{d}$ & {$\left[\mathrm{~mol} \mathrm{~m}^{-3}\right]$} & $\begin{array}{l}\text { Langmuir isotherm equilibrium } \\
\text { constant }\end{array}$ \\
\hline $\mathrm{k}_{\mathrm{f}}$ & {$\left[\mathrm{m}^{3} \mathrm{~mol}^{-1} \mathrm{~s}^{-1}\right]$} & rate constant of forward reaction \\
\hline$k_{L}$ & {$\left[\mathrm{~m} \cdot \mathrm{s}^{-1}\right]$} & liquid-solid mass transfer coefficient \\
\hline$k_{r}$ & {$\left[\mathrm{~s}^{-1}\right]$} & rate constant of reverse reaction \\
\hline$m$ & {$[\mathrm{~kg}]$} & mass of dry resin \\
\hline q & {$\left[\mathrm{mol} \cdot \mathrm{kg}^{-1}\right]$} & $\begin{array}{l}\text { concentration of adsorbate in } \\
\text { adsorbent }\end{array}$ \\
\hline $\mathrm{q}_{\mathrm{m}}$ & {$\left[\mathrm{mol} \cdot \mathrm{kg}^{-1}\right]$} & maximum adsorption capacity of resin \\
\hline $\mathrm{q}_{0}$ & {$\left[\mathrm{~mol} \cdot \mathrm{kg}^{-1}\right]$} & $\begin{array}{l}\text { dynamic capacity of resin which is in } \\
\text { equilibrium with } c_{0}\end{array}$ \\
\hline Q & {$\left[\mathrm{m}^{3} \mathrm{~s}^{-1}\right]$} & liquid flow rate \\
\hline$t$ & {$[\mathrm{~s}]$} & time \\
\hline$T$ & {$\left[{ }^{\circ} \mathrm{C}\right]$} & temperature \\
\hline$u$ & {$\left[\mathrm{~m} \cdot \mathrm{s}^{-1}\right]$} & superficial liquid velocity \\
\hline$V_{0}$ & {$\left[\mathrm{~m}^{3}\right]$} & $\begin{array}{l}\text { volume of free settled resin particles in } \\
\text { the reactor }\end{array}$ \\
\hline$V_{O g}$ & {$\left[\mathrm{~m}^{3}\right]$} & $\begin{array}{l}\text { volume of free settled glass beads in the } \\
\text { reactor }\end{array}$ \\
\hline$V$ & {$\left[\mathrm{~m}^{3}\right]$} & volume of the reactor \\
\hline$z$ & {$[\mathrm{~m}]$} & axial coordinate along the column \\
\hline
\end{tabular}

Greek symbols

$\begin{array}{ll}\varepsilon_{0} & {[-]} \\ \varepsilon_{\mathrm{p}} & {[-]} \\ \varepsilon_{\mathrm{r}} & {[-]} \\ \eta & {[-]} \\ \theta & {[-]} \\ \theta_{\mathrm{b}} & {[-]} \\ \rho & {\left[\mathrm{kg} \cdot \mathrm{m}^{-3}\right]} \\ \rho_{\mathrm{ap}} & {\left[\mathrm{kg} \cdot \mathrm{m}^{-3}\right]} \\ \rho_{\mathrm{ps}} & {\left[\mathrm{kg} \cdot \mathrm{m}^{-3}\right]} \\ & \\ \mu & {[\mathrm{mPa} \cdot \mathrm{s}]} \\ \tau & {[\mathrm{s}]} \\ \tau_{\mathrm{m}} & {[\mathrm{s}]} \\ \xi & {[-]} \\ \xi & {[-]} \\ \psi & \end{array}$

settled bed porosity particle porosity reactor porosity usable efficiency of total capacity of adsorbents dimensionless time break dimensionless time density of liquid solution apparent particle density mass of dry resin per unit volume of swollen resin liquid viscosity hydraulic residence time time required for saturating all the resin in reactor dimensionless solid phase concentration resistance time number to saturate all the resin in reactor

\section{References}

[1] McDougall, G. J.; Fleming, C. A., Extraction of precious metals on activated carbon, in Ion Exchange and Sorption Processes in Hydrometallurgy, Ed. by Streat, M. and Naden, D., Critical Reports on Applied Chemistry 19 (1987) pp. 56-126.

[2] Clifford, D.; Zhang, Z., Modifying ion exchange for combined removal of uranium and radium, J. Am. Water Works Assoc. 86 (1994) pp. 214-227.

[3] Becker, N. S. C.; Eldridge, R. J., Selective recovery of mercury(II) from industrial wastewaters. II. Anion exchange of $\mathrm{Hg}(\mathrm{II})$ chlorocomplexes, React. Polym. 22 (1994) pp. 131-138.

[4] Petruzzelli, D.; Tiravanti, G.; Santori, M.; Passino, R., Chromium removal and recovery from tannery wastes: Laboratory investigation and field experience on a $10 \mathrm{~m}^{3} / \mathrm{d}$ demonstration plant, Wat. Sci. Tech. 30 (1994) pp. 225-233.

[5] Petruzzelli, D.; Passino, R.; Tiravanti, G., Ion exchange process for chromium removal and recovery from tannery wastes, Ind. Chem. Eng. 34 (1995) pp. 2612-2617.

[6] Yang, J.; Menoud, P., Adsorption de métaux lourds à l'aide de la résine Chelamine, Compte-rendu 1, EPF, Lausanne 1994.

[7] Schmidt, V., Développement d'un système fluidisé pour la récupération des métaux lourds des eaux industrielles par des résines chélatantes, Thèse No. 1247, IGC-DC, Ecole Polytechnique Fédérale, Lausanne 1994.

[8] Biscans, B., Chromatographie d'échange d'ions en couche fluidisée. Extraction des protéines du lactosérum, Thèse ENSIGC, Toulouse 1985.

[9] Biscans, B.; Riba, J. P.; Couderc, J. P., Continuous equipment for ion exchange in a fluidized bed. Prospects and problems, Int. Chem. Eng. 28 (1988) pp. 248-256.

[10] Han, K. N; Liu, J., Removal of cadmium and zinc ions by liquid fluid-beds, in: Emerging Proc.Technol. Cleaner Environ. Proc. Symp., Soc.Min. Metall. Expl., Littleton. Colo 1992, pp. 175-183.

[11] Zarraa, M. A., Mass transfer during the removal of dissolved heavy metals from wastewater flows in fluidized beds of ion exchange resins, Chem. Eng. Technol. 15 (1992) pp. 21-25.

[12] Nakamura, S.; Ito, Y.; Iwafuchi, K.; Shirakashi, M., Improvements in uranium adsorption ability of a circulating fluidized bed adsorber, J. Japan Chem. Eng. 27 (1994) pp. 32-38.

[13] Huang, L.; Hao, O. J.; Chen, J. M.; Buglass. R. L., Metal toxicity on sulfate reducing bacteria, in: Proceedings of 25th Mid-Atlantic Ind. Waste Conf (1995) pp. 541-550.

[14] Menoud, P., Récupération de métaux lourds par une résine chélatante, Thèse No. 1563, IGC-DC, Ecole Polytechnique Fédérale, Lausanne 1996.

[15] Menoud, P.; Cavin, L.; Renken, A., Modeling of heavy metals adsorption to a chelating resin in a fluidized bed reactor, Chem. Eng. Proc. 37 (1998) pp. $89-101$.

[16] Jeanneret-Gris, G., Brevet européen, 03623251990.

[17] Yang, J.; Renken, A., Intensification of mass transfer in liquid fluidized beds with inert particles, Chem. Eng. Proc. 37 (1998) pp. 537-544.

[18] Boyer, P. M.; Hsu, J. T., Effect of ligand concentration on protein adsorption in dye-ligand adsorbents, Chem. Eng. Sci. 47 (1992) pp. 241 251.

[19] Arnold, F. H.; Blanch, H. W., Analysis of affinity Chromatography. II. Rate theory and the measurement of biological binding kinetics, $J$. Chromat. 355 (1986) pp. 13-27.

[20] Yang, J., Hydrodynamics and liquid-solid mass transfer in non-conventional fluidized beds, Thesis No. 1919, IGC-DC, Ecole Polytechnique Fédérale, Lausanne 1998.

[21] Cavin, L., Etude cinétique de la désorption de métaux lourds sur la résine Chélamine par complexation avec un polymère soluble, Travail de diplôme, EPF, Lausanne 1996.

[22] Koloini, T.; Zumer, M., Ion exchange with irreversible reaction in deep fluidized beds, Canadian Chem. Eng. 57 (1979) pp. 183-190.

[23] Horstmann, B. J.; Chase, H. A., Modeling the affinity adsorption of immunoglobulin $\mathrm{G}$ to protein immobilized to agarose matrices, Chem. Eng. Res. Des. 67 (1989) pp. 243-254.

[24] Confédération Helvétique, Ordonnance sur le déversement des eaux usées, Ordonnance 814.225.21, (1975) pp. 1-16.

[25] Hartinger, L., Handbuch der Abwasser und Recycling Technik, 2nd ED. Carl Hanser Verlag, München, Wien 1991. 